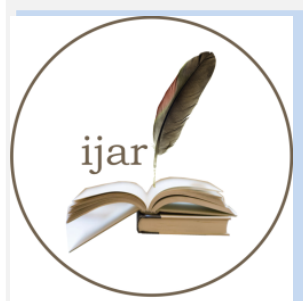

ISSN NO. 2320-5407

\section{Journal Homepage: - www.journalijar.com INTERNATIONAL JOURNAL OF ADVANCED RESEARCH (IJAR)}

Article DOI: 10.21474/IJAR01/6314

DOI URL: http://dx.doi.org/10.21474/IJAR01/6314
INTERNATIONAL JOURNAL OF ADVANCED RESEARCH (JJAR)

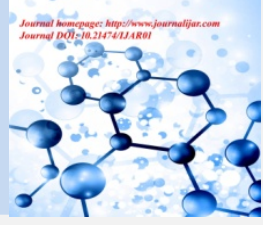

RESEARCH ARTICLE

\title{
INTERPRETERS OF THE ITALIAN LANGUAGE IN THE UNITED STATES BALANCE OF POWER OR POWER IN THE BALANCE?
}

\author{
Claudia Monacelli.
}

UNINT, Rome.

\section{Manuscript Info}

Manuscript History

Received: 15 November 2017

Final Accepted: 17 December 2017

Published: January 2018

\begin{abstract}
At a time when all countries are influenced - in one way or another by globalization, one of the constraints felt the world over is the need for people to communicate in a language other than their own. By and large, this issue is often addressed through the use of interpreters that make it possible for interaction with local institutions. This is a phenomenon that cyclically occurs when there is a mass displacement of people crossing boundaries, inevitably leading to skewed power relations in a critical socio-political backdrop. We discuss issues of power in relation to language in this context. The study examines how the language constraint during Italian migration to the United States represented one of the major challenges and how the interpreting profession for the Italian language took root amidst the ever-changing political and social context. This is then contrasted with the interpreting profession today. Professional interpreters with Italian as one of the working languages in the U.S. reported stark differences in questionnaire and interview findings. Differences involve both the regulation of the profession and the amount of work that has diminished over recent years due to an overriding desire to speak the local language, English, rather that opting to speak their native language, Italian.
\end{abstract}

Copy Right, IJAR, 2018,. All rights reserved.

\section{Introduction}

This work aims to offer an account of interpreting services of the Italian language in the United States by analyzing their origin and subsequent evolution from the perspective of power and ideology as represented in interpretermediated encounters. The analysis spans the period between the late 19th century and today.

At the time of mass migration to the U.S., millions of Italians moved overseas. The movement of such a mass quantity of people caused numerous problems that immigrants had to face in their daily lives (Bevilacqua et al. 2005, Crispino 1980, Daniels 2002). The difficult economic and social situations were also heightened by having to communicate in a new language (LaGumina et al. 2000). For the most part, immigrants were guaranteed the right to speak their own language in legal settings. But, at the time, professional interpreters of this language combination were few and far between, which is conceivable, given the high number of interpreter-mediated contexts that emerged during that period. This is a phenomenon that cyclically occurs when there is a mass displacement of 
people crossing boundaries (Antonini et al. 2017), inevitably leading to skewed power relations in a critical sociopolitical backdrop.

This study examines the dynamics of power relations in the legal and political spheres $(\S 2)$, then provides a description of the origins and subsequent development of the Italian presence in the United States ( 33$)$. The actions of important figures who acted as interpreters, pioneers of this activity in the U.S., is then discussed (§4). The final sections of this paper analyze the findings of a questionnaire distributed to professional interpreters (followed up by phone interviews) who currently work in the US. These findings are considered in light of the changing role of interpreters and, consequently, of their position with regard to cultural power structures (Monacelli 2009).

\section{Is it possible to balance power?}

Power is one of the most elusive concepts in the social and political sciences, partly because there are so many competing definitions, and partly because many key decisions are made behind closed doors, making for confidential settings (Monacelli and Boyd 2016). At the same time, the analysis of power is crucial to our understanding of the contexts in which we work. Examining the processes and structures of power leads us to develop knowledge of the forces that shape our organizations, institutions, relationships and, as a consequence, our own opportunities and experiences, both as professionals and analysts (Martin 2016, Monacelli and Boyd 2017).

Exploring the fundamentally oral nature of interpreting, Michael Cronin calls for a 'cultural turn', which would entail explicitly dealing with issues of power since, throughout history: "the role of interpreters has been crucially determined by the prevailing hierarchical constitution of power and their position in it" (Cronin 2002: 387). Cronin highlights the social framework within which interpreters operate that needs to be foregrounded, in an attempt to illuminate the linguistic and cultural boundaries interpreters cross. He cites Anderson (1976) as having anticipated a possible cultural turn through his investigation of the variables of social class, education, gender, age, and situational factors, such as arena of interaction (political, military, academic, religious) and levels of tension, where he also pointed to factors concerning the prestige of groups involved in the mediated communicative event and attitudes towards the languages spoken (Cronin 2002: 391).

Yet, power struggles are not always related to observable behavior and - more realistically - they can be described as unfolding developments of inclusion and exclusion (Wodak, 2009). In cases such as these, the power(ful) have access to particular discourse related to ritualistic or procedural language, above all in formal settings such as courtrooms or other legal and law enforcement settings, and the power(less) usually appear to be on the receiving end of power(ful) language, which may take the form of interrogations, cross-examinations or investigations. This validation of power leads us to both Bourdieu's notion of violence symbolique (1991) and Gramsci's notion of hegemony (1971). In these approaches to power, the overt and covert techniques, along with power forces, are addressed in language that can be deconstructed using discourse analysis (Wodak 2009: 36). Unfortunately beyond the scope of this paper, a discourse analytical approach to the archives of the Sacco and Vanzetti trial in the U.S. $(\S 4.4)$ would certainly generate food for thought in this sense. ${ }^{1}$

It is important to point out that the domains of politics and the law are related to the media, since both journalists and politicians/attorneys/judges mutually depend on each other. Together they wield power in the construction of meaning, creating symbols which the public can access (Ciaglia 2013).

Linked to this, the notion of legitimacy in the political and legal sphere merits clarification. Sociologist Max Weber conceived of legitimacy as a social fact that binds a social order (Weber 1978: 31). He differentiated between three different types of legitimate authority: legal-rational, charismatic and traditional. For an assessment of power within the framework of our analysis, the most relevant of these is legal-rational authority. This type of authority presents

${ }^{1}$ See Commonwealth of Massachusetts vs. Bartholomeo [sic] Vanzetti and Commonwealth of Massachusetts vs. Nicolo [sic] Sacco in relation to the substitution of pistol barrels in court exhibit pistols (Grippo 2011). 
as being the most stable system, since it is grounded on rationality and logic and therefore is premised on a belief in the formalized and legitimated procedures which bring forth rules and enacts legal proceedings, making it possible to reach decisions (ibid.: 279). Basically, even if individuals may not share the norms underpinning authority and social order in a given society, they would indeed believe them to be legitimate because they are embedded in a system of social controls (Wodak 2009: 37). We thus begin to see how a balance of power in the spheres of politics and law may seem to be an illusion. This is the impression we get when examining the period of Italian mass migration to the United States.

\section{Italians in the U.S.A.}

Prior to 1880 there was a period when craftsmen, merchants, intellectuals, artists, doctors and musicians emigrated from Italy at regular intervals, instilling in the minds of Americans that Italy was a land of art and culture. This all changed on 14 March 1891 when eleven Italian-Americans in New Orleans, Louisiana, were lynched for their alleged role in the murder of police chief David Hennessy. The lynching took place the day after the trial of nine of the nineteen men indicted in the murder. Six of these defendants had been acquitted, and a mistrial declared for the remaining three because the jury had failed to agree on their verdicts. There was widespread suspicion that an Italian network of criminals had generated the killing of the police chief in a period of rising crime. Believing the jury had been bribed, a mob broke into the jail where the men were being held and killed eleven of them. The mob numbered in the thousands and included some of the city's most prominent citizens. American press coverage of the event was largely congratulatory, and those responsible for the lynching were never charged (Bonanno 2007).

The incident had serious national repercussions for both countries. Italy cut off diplomatic relations with the United States that, in turn, called for restrictions on immigration in answer to increased anti-Italian sentiment. We might speculate that this is when the word 'Mafia' started to emerge in the American lexicon, and a particular stereotype of the Italian-American became established in the collective imagination. In spite of this, railway companies across the United States still needed a work force and it was against this backdrop that mass Italian immigration to the U.S. once again began (Daniels 2002).

Initial difficulties that all immigrants had to face after arriving in the United States basically amounted to two, practical ones: they had to find housing and - for those unable to work for railway companies - a job. These problems were compounded by the fact that most had no knowledge of the English language. Within Italian ethnic communities, the person who took it upon themselves to resolve these problems was the padrone, also called the 'boss' who - in exchange for a fee, called bossatura - acted as a social mediator between newly arrived immigrants and civil society. During the 1920s those who took on the role of the padrone were the so-called prominenti who were ethnic leaders generally working as school teachers, journalists or employees heading different forms of mutual aid societies. For the most part on the marge of the lower middle class, the prominenti were not typical, upright citizens, since they were linked to the mob or organized crime in some way or another. The padrone system terminated due to a number of factors, including the mounting charges pressed against them by social workers who aimed to improve the conditions of working immigrants. It was believed that immigrants who better integrate into the new society would favor the passing of laws protecting workers' rights. The padroni were ultimately substituted with certified agents whose job it was to recruit workers for the various railway companies (Nelli 1970).

The lives and history of European immigrants during mass migratory waves were neglected by American scholars for the most part, mainly due to the widespread notion of the 'melting pot' in the U.S. society and culture in the 1910s (Pretelli 2011). This subsequently gave way to the Americanization movement in the 1920s supported by the federal government, industries, trade unions and philanthropic organizations that openly fostered English language courses and civics classes for immigrants (King 2000). 
Italian-Americans struggled to rid themselves of the stereotypes that once labelled their parents and grandparents, and to claim their active role in building the United States identity. During this period, ethnic revival and a rediscovery of national pride became values that contributed to what came to be known as the American Mosaic (Morrison and Zabusky 1993, Vezzosi 2005). Ultimately it was around the 1970s, through organizations such as the Americans of Italian Descent, the Sons of Italy in America, and the National Italian American Foundation, that widespread anti-defamation campaigns against negative imagery had mounted (Nelli 1983).

In this brief coverage of the Italian presence in the U.S. we can single out two channels of communication that held the power to focus the spotlight on events and to influence the minds of the public: the press and literature. This clearly highlights the relevance of language in a play for power. It was amidst the enhanced presence of Italians on North American soil that the role of the interpreter of the Italian language emerged. Throughout the $20^{\text {th }}$ century interpreters have offered language assistance to newcomers from their arrival on Ellis Island for any legal matters or medical issues, in an effort to strike the power balance between them and host country institutions. Following Cronin's plea for a cultural turn (ibid.), it is easy to deduce how much power an interpreter may hold in interpretermediated contexts in this period. The following section delves more deeply into this.

\section{The pioneers of Italian-English interpreting in the U.S.}

Italian-English interpreting services in the U.S., as we know of them today, take their roots from the years of mass emigration from the Bel Paese. The massive flow of arrivals put the authorities in a position of requiring language assistance, if not only for the safety and well-being of immigrants. The majority of Italians only spoke their local Italian dialect at the time and not all spoke what was considered to be standard Italian.

Those conversant in both languages - although not professional interpreters - stepped in at the service of their fellow citizens. Often these people came from other trades or services. Among the most well known figures that served as interpreters are Mother Francesca Saverio Cabrini, patron saint of the immigrants ( $\$ 4.1$ ), along with police officer Joe Petrosino (\$4.2) and the man who is still remembered today as one of the most important mayors of the Big Apple, the Italian-American Fiorello La Guardia (\$4.3). We end this section describing the work of interpreters during the Sacco and Vanzetti trial in the U.S (§4.4), which proved to highly influence the course of events.

\subsection{Mother Francesca Cabrini}

At the time of Italian immigration, the clergy was assisted by women in charge of domestic work, above all in male religious congregations. It was in this historical context that the bishop of New York, Monsignor Michael Augustin Corrigan, accepted the proposal of the bishop of Vicenza, Monsignor Scalabrini, authorized by Pope Leone XIII, to bestow this work on a nun from Lombardy, Mother Francesca Saverio Cabrini. Although quite young, she had already become well known in Italy for her dynamism in founding the new congregation of the Missionary of the Sacred Heart of Jesus.

She received the opportunity to rise to the ranks in the U.S., becoming instrumental in seeking out contexts that urgently required attention with respect to restoring immigrants' dignity. Besides legal matters and employment, another area that proved to be a challenge in relation to immigration, was matters of health. In terms of legal issues, Mother Cabrini and her sisters would plea for retrials and would turn around sentences in favor of immigrants who were penalized for not knowing the English language, thus not receiving fair legal representation. They would also visit prisoners who were sentenced to life and organized conferences weekly in Chicago prisons (Scaraffia 2003: 75).

Another matter of difficulty was generated by immigrants' living conditions that provoked the onset of all types of illnesses, leading to the need for health assistance during this period. The Columbus, a hospital built by Italian philanthropists, gave immigrants medical respite. However, the mismanagement of the institute in the hands of nonreligious organizations was followed by even worse management by the Scalabrini Fathers. Mother Cabrini had 
several times refused the offer to manage the hospital, because she felt she was not competent to work in the area of health. She was a teacher, as her fellow sisters were. She had always worked with orphanages and schools and above all she had no experience with running a hospital. However, were the Columbus to close, the Italian immigrants would be the ones to suffer. Therefore, Mother Cabrini rolled up her sleeves and was able to restore the hospital to its full functions. The Columbus not only dispensed health care and assistance, but also moral and spiritual support to Italian immigrants. Physicians mainly spoke English and little Italian, thus the presence of the sisters was propitious, since they offered not only spiritual guidance but language mediation, having learned several of the languages of immigrants in the U.S. Added to this was the economic edge that Mother Cabrini's management of the hospital offered patients from all ethnic backgrounds. Alongside free health care, the practice of offering paid services allowed the hospital to make use of these funds to add extensions to other institutes already in place and to create new ones (Scaraffia 2003: 50).

\subsection{Officer Joe Petrosino}

The adverse social and economic conditions of Italian immigrants in the U.S. between the mid $19^{\text {th }}$ and $20^{\text {th }}$ centuries, along with the arrival of criminals at large or pending trial, all favored the emergence of racketeers and later led to fully blown organized crime. When the Sicilian Mafia entered the U.S., there already were other ethnic groups of racketeers, such as the Irish and the Jewish, but soon the Italians numerically far outweighed all other groups (Petacco 1972: 3). This ghettoization was more characteristic of larger cities. Critical issues of law and order that the city of New York experienced during this historical period were - to a large degree - due to the arrival of shady individuals which led to stepped up law enforcement in that city.

In order to contain rampant lawbreaking, the police force hired new agents from the ranks of Jewish and Irish immigrant families in New York. A change in this nationalistic streak came in 1883 when a young agent named Joe Petrosino was hired (Petacco 1972). During those years there were about half a million Italian immigrants living in the city of New York and, even if they made for only $4 \%$ of the urban population, it was estimated that $46 \%$ of all homicides were committed by them. Since Irish police officers were not sufficiently able to contrast this criminal activity because they did not know the Italian language, in 1905 a special squad called the Italian Branch was instated. This investigating unit, led by Joe Petrosino, was made up of 5 officers of Italian descent, far too few for the over five hundred thousand people of Italian descent in the city of New York (ibid.). The efficiency of their work led to the addition of thirty more Italian-American agents to the Branch, which later changed its name to the Italian Legion. Knowledge of the Italian language and of different dialects, specifically southern Italian dialects, allowed them to make over 2,500 arrests, deporting about 500. The Italian Legion brought to light a complex, organized network of criminal activity known as the Mano Nera that originated in Sicily (ibid.: 6-10). Though strictly not interpreters, these officers indeed practiced a form of language mediation that served to favor contact with criminals of Italian origin.

\subsection{Mayor Fiorello La Guardia}

Fiorello La Guardia was the son of an Italian father and a Jewish mother from Austria-Hungary. After working as a clerk at the American consulate in Budapest in 1903 and a consular agent for emigration at the Port of Fiume (now Rijeka, Croatia) from 1903 to 1906, he returned to New York to study law at night school. From 1907 to 1910 he worked as an interpreter at Ellis Island while studying law. He was certified to work with the following languages: Italian, German, Yiddish and Croatian (Jeffers 2002: 31-33). After getting his degree, La Guardia left Ellis Island to become a lawyer and eventually entered politics as a progressive Republican. He served as United States Congressman from 1917 to 1919 and again from 1923 to 1933 . He was also a popular three-term mayor of New York City from 1934 to 1946. 
La Guardia (1948) wrote of his experience as an interpreter when he worked on Ellis Island, specifically describing the unyieldly consequences of translation on immigrants. He explains how an unsuitable or misleading translation was the cause for defining immigrants' health as afflicted by mental illness. In these cases, immigrants were immediately deported. According to La Guardia, more than half of all deportations came about because resident physicians at Ellis Island could not fully comprehend immigrants' behavioral patterns, their mental or emotional state, nor their responses to questions posed (ibid.: 65).

Scholars describe immigration history as largely focused on eugenics, the restriction of immigrants by race and ethnicity, distinguishing disability as a crucial factor in the shaping of 'undesirable immigrants' that came to be known as 'defectives' (Baynton 2016). Disabled individuals were not the only ones to be excluded; particular races and nationalities were also 'branded' as undesirable based on their susceptibility to mental, moral, and physical defects. Italians were one of these. However, La Guardia nurtured suspicions that misconstrued translations were at the basis of labelling a number of immigrants from western and southern Europe as mentally instable Even the Italian St. Raphael Society, the main Catholic organization assisting Italian immigrants in the United States between 1890 and 1923, accused physicians at Ellis Island of having mistaken issues relating to language or culture, for signs of mental illness.

\subsection{The Sacco e Vanzetti Trial: Interpreters Joseph Ross and Angelina De Falco}

Nicola Sacco e Bartolomeo Vanzetti, Italian immigrants who were "without influence, wealth, or power" (Grippo 2011: 2) hit news headlines in 1920 and for the following seven years took part in an extensive legal battle to defeat U.S. prejudice and injustice on their behalf. When the two Italian-Americans were accused of robbery in relation to the Slater \& Morril Shoe Company in South Braintree, a suburb of Boston, and of murdering its two employees Frederick Parmenter and Alessandro Berardelli, the social climate in the U.S. was deeply influenced by the so-called Red Scare, generating genuine obsession with regard to communist thought in the period 1917 to 1920 . The conviction that communist advocates might infiltrate the ranks of immigrants and destroy the American political system by establishing a communist stronghold indeed instigated deep-seated opposition to and discrimination against potential suspects (Tejada 2012, Bortman 2005).

Both active anarchists, Sacco and Vanzetti corresponded perfectly to the image of political subversives. Without detailing the legal procedure, widely discussed in numerous publications, it is interesting to focus our attention on those who acted as interpreters during the trial. In a letter to Governor Fuller of Massachusetts, Bartolomeo Vanzetti expressed his dismay concerning the appointment of Joseph Ross as his interpreter. Ross was an acquaintance of Webster Thayer, a Superior Court judge presiding over the case. During the entire trial Ross had given Thayer a ride to and from the courthouse and had even named his child - born during the trial - Webster Thayler Ross. Inter alia, shortly thereafter Joseph Ross went on to serve a sentence for corruption (Joughin and Morgan 1948). Another interpreter was appointed who was linked to a proposal to free Sacco and Vanzetti.

Toward the end of the 1920s anarchist Beniamino Cicchietti contacted the Sacco and Vanzetti Defense Committee with the proposal of liberating them, at a price. Suspicious of the idea, the Committee Treasurer Aldino Felicani organized a meeting to discuss it. On 2 January 1921, when the charges and witnesses against the defendants seemed to have already convicted them, and when public opinion was divided with respect to their innocence, Cicchietti went to the Committee with a young woman he introduced as Angelina De Falco, a court interpreter and good friend of the prosecutor in the trial, Fred Katzmann. She explained that a verdict of not guilty could have been handed down if Katzmann's brother, Percy, and Attorney Francis J. Squires were to be hired to defend them in lieu of their lawyer at the time, Fred Moore. Therefore, with his brother as a defense lawyer, Fred Katzmann would have had to pass the case to one of his assistants. The District Attorney and his aides, along with a member of the jury, would all have had to be bribed, according to De Falco. A mock trial would have then ensued and they would have been freed (Young and Kaiser 1985, Tejada 2012). Angelina De Falco negotiated the price of their freedom on the basis of Sacco's prior conviction for the crime committed in Bridgewater (Watson 2007: 403). 
The anarchists subsequently met with both Cicchietti and De Falco. The talks were conducted in Italian. Sacco and Vanzetti's attorney, Fred Moore, was not aware of their dealings with De Falco but indeed found out about them. De Falco organized a dinner at her house to endorse the agreement but Moore advised Felicani against participating and suggested he stall. Nonetheless, that evening Felicani drove by De Falco's home in time to see three cars parked outside. The license plates revealed they belonged to the Katzmann brothers and to Attorney Squires. To clarify matters, the treasurer set a meeting with De Falco at the Sacco and Vanzetti Defense Committee headquarters. A hidden microphone in the room and a stenographer made it possible to gather evidence of attempts to corrupt and Angelina De Falco was arrested. Although she was tried and declared not guilty, her subsequent activity landed her a conviction in 1931 for extortion (Watson 2007).

We are by no means here suggesting that interpreters Ross and De Falco are the reason Sacco and Vanzetti were convicted. We are suggesting, all the same, that they indeed held enough power to alter the course of events.

\section{Interpreters of the Italian language in the U.S. today}

According to AIIC, the International Association of Conference Interpreters, there are about 200 members with a language combination that include English and Italian, distributed over 50 cities in the world. Roughly twenty of these work in the United States. The political and economic weight of the U.S. on the international scene puts it in the position of hosting international events, making it necessary for them to communicate even via interpreters.

Who are the interpreters of the Italian language in the U.S. today? We distributed questionnaires to AIIC interpreters with this language combination, whose professional domicile is in the U.S. Twelve active professionals were contacted via email, nine women and three men; half of them responded and expressed their willingness to participate in this study. The questionnaire consisted of thirty questions that covered personal data, language combinations, formal training, their professional profile, settings in which they work, and those sectors currently employing Italian/English interpreters in the U.S. We followed-up with telephone interviews for further clarification. This section reports on findings that emerged from the questionnaire; all relevant data are presented in tabular format.

\begin{tabular}{|c|c|c|c|c|}
\hline Respondent & Gender & Date of birth & Country of birth & Country of residence \\
\hline $\mathrm{I}^{1}$ & $\mathrm{~F}$ & 1931 & Italy & USA \\
\hline $\mathrm{I}^{2}$ & $\mathrm{~F}$ & 1942 & Italy & USA \\
\hline $\mathrm{I}^{3}$ & $\mathrm{~F}$ & 1951 & Italy & USA \\
\hline $\mathrm{I}^{4}$ & $\mathrm{~F}$ & 1963 & Italy & USA \\
\hline $\mathrm{I}^{5}$ & $\mathrm{M}$ & 1965 & Italy & USA \\
\hline $\mathrm{I}^{6}$ & $\mathrm{~F}$ & 1975 & Colombia & \\
\hline
\end{tabular}

Table 1. Personal data of respondents ${ }^{2}$

As you can see from Table 1, ages of the five female and one male respondents range from $86\left(\mathrm{I}^{1}\right)$ to $42\left(\mathrm{I}^{6}\right)$. The interesting factor here to note is that all participants are first generation foreign born, one being of Colombian extraction, suggesting that her language combination may be somewhat different in relation to her 5 other colleagues. Respondent $\mathrm{I}^{1}$ ended her professional career in 2007.

Table 2 informs on specific language combinations of each participant. Working languages are classified into three categories: A, B, and C. An 'A' language is the interpreter's native tongue (or an equivalent) into which they work, from all their other working languages. A ' $\mathrm{B}$ ' language is a language other than the interpreter's native language, of which they have a perfect command and into which they work. A ' $\mathrm{C}$ ' language is considered a passive language, i.e.

${ }^{2}$ For the purpose of anonymizing data, subjects participating in the questionnaire correspond to the letter ' $\mathrm{I}$ ' (interpreter) and an ordinal number in superscript. 
a language of which interpreters have complete understanding and from which they work. All respondents have English as a B language, which means they have migrated to the U.S. at some point in time.

\begin{tabular}{|c|c|c|c|}
\hline Respondent & A language & B language & C language \\
\hline $\mathrm{I}^{1}$ & Italian & English & French/Spanish \\
\hline $\mathrm{I}^{2}$ & Italian & English & French/Spanish \\
\hline $\mathrm{I}^{3}$ & Italian & English & French/Spanish \\
\hline $\mathrm{I}^{4}$ & Italian/German & English & \\
\hline $\mathrm{I}^{5}$ & Italian & English & Italian \\
\hline $\mathrm{I}^{6}$ & Spanish & English & \\
\hline
\end{tabular}

Table 2. Language combination of respondents

All also have 3-4 working languages, with the except of respondent $\mathrm{I}^{5}$ whose combination includes Italian and English, with no $\mathrm{C}$ languages. The male respondent $\mathrm{I}^{4}$ is the only bilingual interpreter (Italian/German), with 2 ' $\mathrm{A}$ ' languages.

French, once considered the language of diplomacy, is also listed as a ' $\mathrm{C}$ ' language for the first three respondents. Along with Spanish (' $\mathrm{A}$ ' language for $\mathrm{I}^{6}$, ' $\mathrm{B}$ ' language for $\mathrm{I}^{1} \mathrm{I}^{2} \mathrm{I}^{3}$ ), French is also among the official working languages for many international institutions in the U.S., such as the United Nations, International Labour Organization, International Monetary Fund, International Telecommunication Union and World Bank, to name a few.

Table 3 lists the respondents' professional activity in terms of the time span, sector and status, i.e. freelance, fulltime staff or in-house officer. This information allows us to understand how Italian-English interpreting services developed.

\begin{tabular}{|c|c|c|c|}
\hline Respondent & Years Working in USA & Sector & Status \\
\hline $\mathrm{I}^{1}$ & $1966-2007$ & Public/Private & Freelance \\
\hline $\mathrm{I}^{2}$ & $1975-$ & Public/Private & Freelance/Officer \\
\hline $\mathrm{I}^{3}$ & $\mathrm{I} 980-1981 \quad 1989-$ & Public & Freelance \\
\hline $\mathrm{I}^{4}$ & $1990-$ & Private & Freelance \\
\hline $\mathrm{I}^{5}$ & $1991-$ & Public & Freelance \\
\hline $\mathrm{I}^{6}$ & $2007-$ & Private & Freelance \\
\hline
\end{tabular}

Table 3. Respondents' professional profile

The oldest respondent $\left(\mathrm{I}^{1}\right)$ has worked as an interpreter for 42 years, and is no longer active in the field today. All other respondents are still active professionally and have been working for a minimum of 10 years $\left(\mathrm{I}^{6}\right.$, the youngest respondent) to a maximum of 42 years, in the case of $\mathrm{I}^{2}$, who is still an active interpreter at the age of 75 years old.

All respondents work or have worked in the public sector and only the two older respondents $\left(\mathrm{I}^{1}\right.$ and $\left.\mathrm{I}^{2}\right)$ have worked in the private sector. All are freelance professionals with the exception of $\mathrm{I}^{2}$ who, at one time during her career, also worked as an in-house officer for an institution in the U.S. This is in line with the fact that - with the exception of Italian Embassies, Italian Cultural Institutes and the U.S. Department of State - Italian is not a working language within international institutions in the U.S., as mentioned. 
Table 4 lists the sectors which have been employing professional Italian-English interpreters and indicates the ongoing market development.

\begin{tabular}{|c|c|c|c|c|c|c|c|c|}
\hline Respondent & Judiciary & Medical & Economic & Institutional & $\begin{array}{c}\text { Trade } \\
\text { Fairs }\end{array}$ & Conferences & Other & Volume \\
\hline $\mathrm{I}^{1}$ & $\sqrt{ }$ & & $\sqrt{ }$ & $\sqrt{ }$ & & $\sqrt{ }$ & $\sqrt{ }$ & Decreased \\
\hline $\mathrm{I}^{2}$ & & $\sqrt{ }$ & & & $\sqrt{ }$ & $\sqrt{ }$ & $\sqrt{ }$ & Unchanged \\
\hline $\mathrm{I}^{3}$ & $\sqrt{ }$ & $\sqrt{ }$ & $\sqrt{ }$ & $\sqrt{ }$ & & $\sqrt{ }$ & $\sqrt{ }$ & Decreased \\
\hline $\mathrm{I}^{4}$ & & $\sqrt{ }$ & $\sqrt{ }$ & & & $\sqrt{ }$ & $\sqrt{ }$ & Decreased \\
\hline $\mathrm{I}^{5}$ & $\sqrt{ }$ & & $\sqrt{ }$ & $\sqrt{ }$ & & $\sqrt{ }$ & Decreased \\
\hline $\mathrm{I}^{6}$ & $\sqrt{ }$ & & & $\sqrt{ }$ & $\sqrt{ }$ & $\sqrt{ }$ & $\sqrt{ }$ & Unchanged \\
\hline
\end{tabular}

Table 4. Sectors that have employed Italian/English interpreters in the U.S.

International conferences offer the most in terms of working days per year. This is followed by three important sectors listed by four respondents: judiciary and legal, institutional, economic sectors. Work in the field of medicine is listed by three respondents as being of relevance to their professional career, but trade fairs are only listed by two respondents as an area of work. This sector, along with tourism, are areas that do not necessarily require highly qualified interpreters.

During interviews it was possible to understand which specific institution each respondent had worked for. $I^{1}$ had worked for the Italian Ministry for Foreign Affairs, White House, U.S. Department of State, Italian President of the Council of Ministers, U.N., NATO, G-7, G-8 and various other Italian and U.S. government bodies. ${ }^{2}$ has worked for the National Institutes of Health (NIH), Italian Embassy, National Geographic Society, World Bank and International Monetary Fund. Respondent $\mathrm{I}^{3}$ also lists the IMF and World Bank and adds the U.N., NATO, UNICEF, ILO and the International Olympic Committee. Respondent $\mathrm{I}^{4}$ indicates mainly working for software companies and law firms. Similar to $\mathrm{I}^{1}, \mathrm{I}^{5}$ also listed working for the Department of State, White House and the Italian President of the Council of Ministers. $\mathrm{I}^{6}$ stated she basically works for the Banco Interamericano de Desarrollo (BID), in regard to their legal matters as well.

In addition to the sectors mentioned, during interviews it was possible to ascertain what "other" sectors they work in. Respondents $\mathrm{I}^{1} \mathrm{I}^{4}$ all have experience working on TV, three of which $\left(\mathrm{I}^{2}-\mathrm{I}^{4}\right)$ also work in the film industry as interpreters. Half of all respondents work with businesses $\left(\mathrm{I}^{1}, \mathrm{I}^{2}, \mathrm{I}^{6}\right)$ or in the courts $\left(\mathrm{I}^{1}, \mathrm{I}^{2}, \mathrm{I}^{4}\right)$; of these, two also work with police stations $\left(\mathrm{I}^{2}, \mathrm{I}^{4}\right)$. Only respondent $\mathrm{I}^{2}$ mentioned that she works in hospitals and trade fairs, the latter also mentioned by $\mathrm{I}^{6}$.

Respondents were also asked whether - from the beginning of their career - the work in specific sectors had increase, decreased, or remained the same. Work in specific sectors, according to two respondents out of six, had remained the same.

One of the final questions involved indicating areas in which Italian-English interpreters may be employed in future. Figure 1 plots responses and makes it possible to compare these indications to responses listed in Table 4 concerning sectors where professional interpreters have been currently employed. 


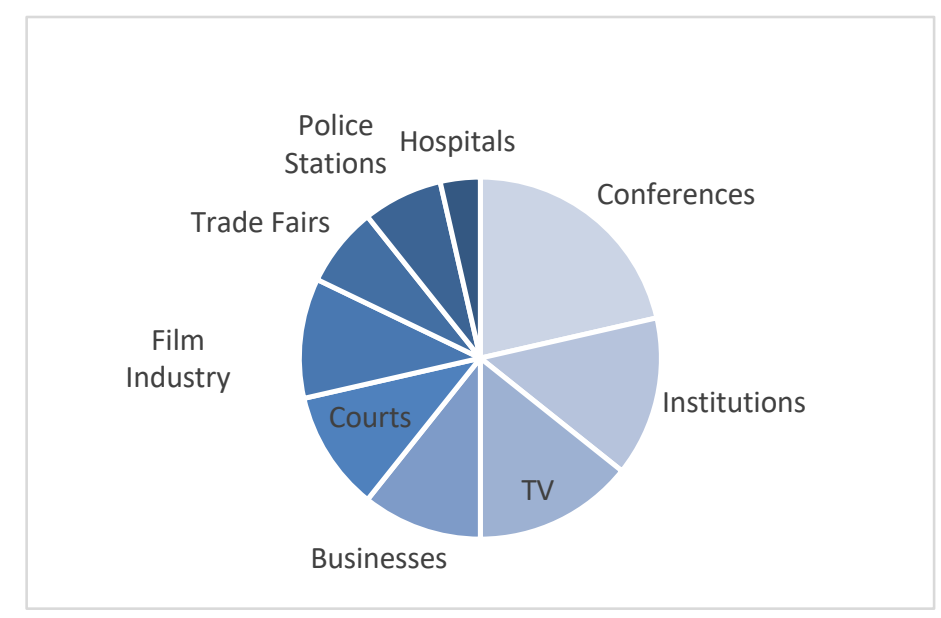

Figure 1. Future projection of sectors to employ professional Italian-English interpreters in the U.S.

In this projection, conferences still seem to have the lion's share of the professional market. TV media interpreting is an area which will be expanding and should equal institutional work. The film industry, similar to work in courtrooms and with businesses, should offer a fair amount of working days per year, but still offering less work with relation to conferences, institutions and TV. Here too, our interviews yielded further details. $\mathrm{I}^{2}$ feels the medical field will offer more work, however not directly related to the context of hospitals, but rather concerning interviews that relate to the health of immigrant. The same respondent also believes there will be a drop in the number of interpreting jobs in political meetings. Interestingly, and in line with this, $\mathrm{I}^{3}$ feels all sectors will experience a decrease of work offered, unless the Italian government starts to protect the Italian language and culture in institutional meetings. Italian delegates currently opt to speak other languages, thus 'impoverishing' the national language both ideologically speaking and with relation to its importance at an international level. Both these issues relate to the construct of power.

\section{Concluding remarks}

During mass migratory flows to the U.S. it is indeed telling that initial aid in the form of language mediation came from social services offered by the clergy ( $\$ 4.1$ ), followed by the institution of law enforcement ( 4.2$)$ and, last but not least, by a future politician ( $\$ 4.3)$. This denotes the changes effected with respect to a balance of power, tipping the scales in favor of newly immigrated Italians to the U.S. Today, far from the migratory flows characterizing the $19^{\text {th }}$ and $20^{\text {th }}$ centuries, we get a glimpse of how - once again - the scales tip, but for different reasons and in the opposite direction.

The final questions asked to respondents addressed any other possible evolution or change the profession has endeared over the years during their career. There were two replies that point to fundamental reasons behind language representation today. Respondent $\mathrm{I}^{1}$ underscores the fact that interpreters are employed - by language depending on the importance a country has for the U.S. in terms of its political and business role in a given point in history. Respondent $\mathrm{I}^{3}$ states that, generally speaking, the fact that most Italians speak little English brings to a situation whereby there is little representation of Italy in the U.S. at institutional, economic and industrial levels.

The limits of this study concern its scope. Although history provides us with the backbone to this paper, professional interpreters today allow us to actually read between those historical lines, even diachronically. And in this sense, we must stress that in the famous Sacco and Vanzetti trial, critical communication difficulties arose because the defendants spoke two, different dialects and because of intentional manipulation by a pro-prosecution interpreter (§4.4), Ms. Angelina De Falco (Jarman 2012: 179). This combination of circumstances may have contributed to the guilty verdict handed down by the jury (Carnevale 2009: 86). 
Language as a social construction is subject to the laws of structural determinism. This is the stance that the pregiven structure of some system - such as language or any kind of textual system - determines the subjectivity (or at least behavior) of individuals who are subjected to it. This seemingly circular reasoning pattern points in the direction of French philosopher Louis Althusser, who was a structural determinist (Althusser 1994). The irony of his experience with the 'trials' and tribulations of a legal system that judged him as insane for the murder of his wife, is not lost on us today.

When viewing any system, in our case a legal system in thus U.S., the fundamental principle of structural determinism is that the behavior of a system is constrained by its constitution. The set of potential changes in a system is circumscribed by (i) the system's range of potential structural transformations, and (ii) the set of potential 'perturbations' (see Maturana and Varela 1998: 95-6) impinging upon the system. While a given perturbation (riots, demonstrations, uproar, etc.) may trigger a change of system state, the particular change triggered is a function of the system's own organization and structure (Monacelli 2009: 49).

If we 'fast forward' and allow ourselves to drift - for just one moment - to another case that was tried against foreign aliens on national soil, we reach the Amanda Knox trial in Perugia, Italy. A crime célèbre in the true sense of the term. For all intents and purposes, it can be considered a postmodern media spectacle. This was the first major criminal case in which social media had such a resounding role in the investigation and initial trial that saw Amanda Knox and Raffaele Sollecito found guilty and sentenced to 26 and 25 years imprisonment respectively (Gies and Bortoluzzi 2016). The rest, of course, is history. Both the 'language' of visual imagery (TV and video recordings) and social media conspired to unveiling varied miscomings of the Italian legal system. And, it was - I surmise - this critical 'doubt' that ultimately allowed the two defendants to go free, for this 'system' represented a globalized world with a structure all its own.

The workings of power in relation to the mass displacement of peoples, as seen in the case of Italian immigrants in the U.S., are chronicled through the prominence in the media of opinion leaders, politicians, and industry spokesmen, concerning their ideological views in relation to these migratory flows (Ciaglia 2013, Daniels 2002, Jarman 2012). This essay aimed to provide food for thought for a future discussion of power and ideology in contexts where globalization and migratory waves lead to changing identities, languages, and cultures through the interface of institutions in the host countries.

\section{References:-}

1. Althusser, L. (1994) [Translated by Richard Veasey] The Future Lasts Forever: A Memoir. New York: New Press.

2. Anderson, R. B. W. (1976) Perspectives on the role of the interpreter. In Translation: Applications and Research, R. W. Brislin (ed.), 208-228. New York: Garner Press.

3. Antonini, R., Cirillo, L., Rossato, L. Torresi, I. (2017) Non-professional Interpreting and Translation: State of the art and future of an emerging field of research. Amsterdam/Philadelphia: John Benjamins.

4. Baynton, D. C. (2016) Defectives in the Land: Disability and Immigration in the Age of Eugenics. Chicago: University of Chicago Press.

5. Bevilacqua, P., Franzina, E., De Clementi, A. (2001) Storia dell'emigrazione italiana: Arrivi. Roma: Donzelli Editore.

6. Bonanno, A. (28/11/2007) Il linciaggio di nove siciliani nella New Orleans del 1891, in La Repubblica. http://palermo.repubblica.it/dettaglio/il-linciaggio-di-nove-siciliani-nella-new-orleans-del-1891/1396533/1 (date accessed 13 September 2017).

7. Bourdieu, P. (1991) Language and Symbolic Power. Cambridge: Polity Press.

8. Bortman, E. C. (2005) Sacco and Vanzetti. Carlisle, Massachusetts: Commonwealth Editions.

9. Carnevale, Nancy C. (2009) A New Language, A New World. Italian Immigrants in the United States, 18901945. Urbana: University of Illinois Press.

10. Ciaglia, A. (2013) Politics in the media and the media in politics: A comparative study of the relationship between the media and political systems in three European countries. In European Journal of Communication 
28(5): 541-555.

11. Crispino, J. (1980) The Assimilation of Ethnic Groups. The Italian Case. Staten Island, N.Y.: Center for Migration Studies.

12. Cronin, M. 2002 The Empire talks back: Orality, heteronomy and cultural turn in interpreting studies. In The Interpreting Studies Reader, F. Pöchhacker and M. Shlesinger (eds.), London/New York: Routledge, 386-397.

13. Daniels, R. (2002) Coming to America. A History of Immigration and Ethnicity in American Life. New York: Perennial.

14. Gies, L., Bortoluzzi, M. (2016) Transmedia Crime Stories. The Trial of Amanda Knox and Raffaele Sollecito in the Globalised Media Sphere. London: Palgrave Macmillan.

15. Grippo, T.W. (2011) With Malice Aforethought - The Execution of Nicola Sacco and Bartolomeo Vanzetti. Bloomington, Indiana: iUniverse.

16. Gramsci, A. (1971) Selections from Prison Notebooks (trans. and eds. Q. Hoare and G. Nowell Smith). London: Lawrence \& Wishart.

17. Joughin, L., Morgan E. M. (1948) The Legacy of Sacco and Vanzetti. Princeton, New Jersey: Princeton University

18. Jarman, F. (2012) Intercultural Communication in Action. Rockville, Maryland (U.S.A.): Wildside Press.

19. Jeffers, P. H. (2002) The Napoleon of New York. Mayor Fiorello La Guardia. New York: John Wiley.

20. King, D. (2000) Making Americans. Immigration, Race, and the Origins of the Diverse Democracy. Cambridge, Massachusetts: Harvard University Press.

21. La Guardia, F. (1948) The Making of an Insurgent: An Autobiography. Philadelphia: J.B. Lippincott.

22. LaGumina, S.J., Cavaioli, F.J., Primeggia, S., Varacalli, J.A. (2000) The Italian American Experience. New York: Garland Publishing.

23. Martin, A. (2016) Interpreting and Ideology: Research trends and methods. In C. Bendazzoli and C. Monacelli (eds.) Addressing Methodological Challenges in Interpreting Studies Research. Newcastle upon Tyne: Cambridge Scholars Publishing, 225-244.

24. Maturana, H. R., Varela, F. (1998) The Tree of Knowledge. Boston and London: Shambala.

25. Monacelli, C. (2009) Self-preservation in simultaneous interpreting, Amsterdam/Philadelphia: John Benjamins.

26. Monacelli, C., Boyd, M.S. (2017) Professional Role and Ethics in Interpreting Studies Research. In M. Biagini, M. Boyd \& C. Monacelli (eds.) The changing role of the interpreter: Norms, ethics and quality standards, London/New York: Routledge, 203-216.

27. Monacelli, C., Boyd, M.S. (2016) Methods to Contextual Madness: Taking what is not given in confidential settings. In C. Bendazzoli \& C. Monacelli (eds.) Addressing Methodological Challenges in Interpreting Studies Research, Newcastle Upon Tyne: Cambridge Scholars Publishing, 31-60.

28. Morrison, J., Zabusky, C. F. (1993) American Mosaic: The immigrant experience in the words of those who lived it. Pittsburg: University of Pittsburg Press.

29. Nelli, H. S. (1970) Italians in Chicago, 1880-1930. A Study in Ethnic Mobility. New York: Oxford University Press.

30. Nelli, H. S. (1983) From Immigrants to Ethnics. The Italian Americans. New York: Oxford University Press.

31. Petacco, A.(1972) Joe Petrosino. Milano: A. Mondadori.

32. Pretelli, M. (2011) L'emigrazione italiana negli Stati Uniti. Bologna: Il Mulino.

33. Scaraffia, L. (2003) Francesca Cabrini. Tra la terra e il cielo. Milano: Paoline Ed. Libri.

34. Tejada, S. (2012) In Search of Sacco and Vanzetti. Lebanon, New Hampshire: University Press of New England.

35. Vezzosi, E. (2005) Mosaico americano. Società e cultura negli Usa contemporanei. Roma: Carocci.

36. Watson, B. (2007) Sacco and Vanzetti. New York: Penguin Group.

37. Weber, M. (1978) Economy and Society: An Outline of Interpretive Sociology. Berkeley, CA: University of California Press.

38. Wodak, R. (2009) The Discourse of Politics in Action. London: Palgrave Macmillan.

39. Young, W., Kaiser, D. E. (1985) Postmortem: New Evidence in the Case of Sacco and Vanzetti. Amherst: University of Massachusetts Press, 1985. 